\title{
DNA relatedness of Leptospira strains isolated from beef cattle in Zimbabwe
}

\author{
Sara B. Feresu, ${ }^{1}$ Arnold G. Steigerwalt ${ }^{2}$ and Don J. Brenner ${ }^{2}$ \\ Author for correspondence: Sara B. Feresu. Tel: +2634303211 . Fax: +2634333407. \\ e-mail: sferesu@esanet.zw or feresu@compcentre.uz.ac.zw
}

\footnotetext{
1 Department of Biological Sciences, University of Zimbabwe, MP 167, Mount Pleasant, Harare, Zimbabwe

2 Meningitis and Special Pathogens Branch, Division of Bacterial and Mycotic Diseases, National Center for Infectious Diseases, Centers for Disease Control and Prevention, Atlanta, GA 30333, USA
}

\begin{abstract}
The DNA relatedness of 17 Leptospira strains isolated from beef cattle in Zimbabwe was determined using the hydroxyapatite method. Similarly to previously speciated African strains, all Zimbabwe isolates belonged to either Leptospira borgpetersenii or Leptospira kirschneri. All serovars within serogroups Pyrogenes (kwale, mombe and a strain closely related to serovar nigeria), Hebdomadis (marondera and mhou), Tarassovi (ngavi) and Sejroe (balcanica and hardjo) were $L$. borgpetersenii. L. kirschneri contained all strains in serovars of serogroups Icterohaemorrhagiae (zimbabwe), Australis (fugis), Bataviae (paidjan) and Pomona (a strain closely related to mozdok). The species designations of the Zimbabwe fugis and paidjan strains were different from those of the reference strains of these two serovars, both of which belong to Leptospira interrogans.
\end{abstract}

Keywords: DNA relatedness, Leptospira borgpetersenii, Leptospira kirschneri

\section{INTRODUCTION}

Leptospira traditionally contained two species, Leptospira interrogans, which consisted of serogroups pathogenic for man and animals, and Leptospira biflexa, with non-pathogenic serogroups (Johnson \& Faine, 1984). DNA relatedness studies demonstrated extreme heterogeneity in both of these nomen species. On the basis of these studies, the family Leptospiraceae was shown to include the genus Leptospira with 12 named and four unnamed species, the genus Leptonema with its single species Leptonema illini and 'Turneria parva' (Yasuda et al., 1987; Ramadass et al., 1992; Perolat et al., 1998; Brenner et al., 1999).

Leptospira isolates are still usually identified serologically, to the level of serogroup and/or serovar, although the serological methods used for identification are laborious, subjective and often not reproducible. Based on this concept, pathogenic strains of Leptospira are divided into more than 220 serovars which are grouped into more than 30 serogroups (Kmety \& Dikken, 1993). A serogroup contains separate but closely antigenically related serovars. Assignment of strains to serogroups is essentially a consequence of the serological typing technique (Kmety \& Dikken, 1993). It is now well-known that serovars and serogroups do not equate with species assignation (Yasuda et al., 1987; Ramadass et al., 1992; Brenner et al., 1999). In some cases antigenically similar strains may be genetically diverse (Yasuda et al., 1987; Ramadass et al., 1992; Gravekamp et al., 1993), while in other cases genetic analyses may fail to distinguish between antigenically different strains (Thiermann et al., 1986; Zuerner \& Bolin, 1990; Herrmann et al., 1991).

A variety of modern genetic analyses have been applied to Leptospira taxonomy in an attempt to reconcile the two approaches. These methods include RFLP of chromosomal DNA (Marshall et al., 1981; Thiermann et al., 1986; Ellis et al., 1991), restriction analysis of chromosomal DNA by PFGE (Herrmann et al., 1991, 1992), DNA hybridization with total DNA probes (Millar et al., 1987; Terpstra et al., 1987; Nielsen et al., 1989), restriction analysis by Southern blotting with recombinant DNA probes (Le Febvre, 1987; Zuerner \& Bolin, 1988, 1990; Van Eys et al., 1991; Woodward \& Sullivan, 1991; Pacciarini et al., 1992; Zuerner et al., 1993), rRNA gene analysis (Hookey, 1990, 1993; Perolat et al., 1990, 1993) and PCR fingerprinting (Van Eys et al., 1989; Hookey, 1992; Mérien et al., 1992; Corney et al., 1993; Gravekamp et al., 1993; Ralph et al., 1993; de Caballero et al., 1994; Perolat et al., 1994; Zuerner et al., 1995; Murgia et al., 1997; Letocart et al., 1997).

Groupings obtained using some of these methods, such as RFLP, PFGE, restriction analysis by Southern blotting with DNA probes and IS1533-based PCR assays, were designed to replace serotyping and generally correlate with serovars, while the rest of the methods support taxa generated in DNA relatedness 
Table 1. Strains used in the study

\begin{tabular}{|c|c|c|c|}
\hline Serogroup & Serovar & Strain & Species assignment \\
\hline \multicolumn{4}{|l|}{ Zimbabwe isolates } \\
\hline \multirow[t]{5}{*}{ Pyrogenes } & kwale & SBF 2 & Leptospira borgpetersenii \\
\hline & mombe & SBF $20^{*}$ & Leptospira borgpetersenii \\
\hline & mombe & SBF 28 & Leptospira borgpetersenii \\
\hline & mombe & SBF 43 & Leptospira borgpetersenii \\
\hline & $($ nigeria $) \dagger$ & SBF 49 & Leptospira borgpetersenii \\
\hline \multirow[t]{4}{*}{ Hebdomadis } & marondera & SBF $5^{*}$ & Leptospira borgpetersenii \\
\hline & marondera & SBF 21 & Leptospira borgpetersenii \\
\hline & marondera & SBF 50 & Leptospira borgpetersenii \\
\hline & mhou & SBF $40^{*}$ & Leptospira borgpetersenii \\
\hline \multirow[t]{3}{*}{ Sejroe } & hardjo & SBF 27 & Leptospira borgpetersenii \\
\hline & hardjo & SBF 41 & Leptospira borgpetersenii \\
\hline & balcanica & SBF 47 & Leptospira borgpetersenii \\
\hline Tarassovi & ngavi & SBF 19 & Leptospira borgpetersenii \\
\hline Icterohaemorrhagiae & zimbabwe & SBF $23^{*}$ & Leptospira kirschneri \\
\hline Australis & fugis & SBF 3 & Leptospira kirschneri \\
\hline Pomona & (mozdok) $\dagger$ & SBF 8 & Leptospira kirschneri \\
\hline Bataviae & paidjan & SBF 37 & Leptospira kirschneri \\
\hline \multicolumn{4}{|l|}{ Reference strains } \\
\hline Icterohaemorrhagiae & icterohaemorrhagiae & $\mathrm{RGA}^{\mathrm{T}}$ & Leptospira interrogans \\
\hline Cynopteri & cynopteri & $3522 \mathrm{C}^{\mathrm{T}}$ & Leptospira kirschneri \\
\hline Panama & panama & $\mathrm{CZ} 214 \mathrm{~K}^{\mathrm{T}}$ & Leptospira noguchii \\
\hline Shermani & shermani & $1342 \mathrm{~K}^{\mathrm{T}}$ & Leptospira santarosai \\
\hline Javanica & javanica & Veldrat Batavia $46^{\mathrm{T}}$ & Leptospira borgpetersenii \\
\hline Manhao & manhao 3 & $\mathrm{~L} 60^{\mathrm{T}}$ & Leptospira alexanderi \\
\hline Celledoni & celledoni & Celledoni $^{\mathbf{T}}$ & Leptospira weilii \\
\hline Codice & codice & Biflexa $\mathrm{CDC}^{\mathrm{T}}$ & Leptospira wolbachii \\
\hline Lyme & lyme & Strain $10^{\mathrm{T}}$ & Leptospira inadai \\
\hline Ranarum & ranarum & Iowa City Frog ${ }^{\mathrm{T}}$ & Leptospira meyeri \\
\hline Andamana & andamana & CH 11 & Leptospira biflexa \\
\hline Undesignated & holland & Waz Holland & Leptospira genomospecies 3 \\
\hline Leptonema & illini & $3055^{\mathrm{T}}$ & Leptonema illini \\
\hline Turneria & parva & $\mathrm{H}^{\mathrm{T}}$ & 'Turneria parva' \\
\hline
\end{tabular}

* Zimbabwe serovar reference strain.

$\uparrow$ Closely related to serovar.

studies. The latter methods even show more heterogeneity within DNA related groupings with several classification systems proposed (Perolat et al., 1990, 1993, 1994; Hookey, 1993; Ralph et al., 1993). However, despite these advances, the differences revealed by the molecular methods have not yet been able to describe the desired host-pathogen relationships required in epidemiological studies, or to justify the complete overhaul of the old system based on antigenic structures. Therefore, it is customary to use a variety of these methods in conjunction with serology when characterizing and/or identifying field isolates.

The isolation of 50 Leptospira strains from kidneys of beef cattle in Zimbabwe and their serogrouping have been reported previously (Feresu, 1992). The isolates belonged to nine serogroups: Australis, Bataviae, Grippotyphosa, Hebdomadis, Icterohaemorrhagiae, Pomona, Pyrogenes, Sejroe and Tarassovi.
Representatives from each of these serogroups have been characterized using various methods, including the cross-agglutinin absorption test, mAb analysis, RFLP of chromosomal DNA, restriction analysis by Southern blotting with recombinant DNA probes, PFGE and PCR fingerprinting (Feresu \& Bolin, 1991; Feresu et al., 1993, 1994, 1995, 1996, 1998, 1999). These studies identified five new serovars: zimbabwe (Icterohaemorrhagiae), mombe (Pyrogenes), mhou and marondera (Hebdomadis) and ngavi (Tarassovi). In the present study, 17 representatives of eight of these serogroups were further characterized for DNA relatedness and assigned to species.

\section{METHODS}

Bacterial strains. Table 1 presents the 17 Zimbabwe strains which were studied and their serological assignments. All isolates were obtained from stock cultures maintained in 
Table 2. Percentage DNA relatedness of Zimbabwean and reference strains

R, Relatedness; D, divergence; ND, not done.

\begin{tabular}{|c|c|c|c|c|c|c|c|c|c|c|c|c|}
\hline \multirow{3}{*}{$\begin{array}{l}\text { Source of unlabelled } \\
\text { DNA serovar/strain }\end{array}$} & \multicolumn{12}{|c|}{ Source of labelled DNA } \\
\hline & \multicolumn{3}{|c|}{ hardjo Hardjo-bovis SBF 41} & \multicolumn{3}{|c|}{ zimbabwe SBF 23} & \multicolumn{3}{|c|}{ mombe SBF 28} & \multicolumn{3}{|c|}{ paidjan SBF 37} \\
\hline & $\begin{array}{l}\mathbf{R}(\%) \text { at } \\
55^{\circ} \mathrm{C}\end{array}$ & D (\%) & $\begin{array}{l}R(\%) \text { at } \\
70^{\circ} \mathrm{C}\end{array}$ & $\begin{array}{l}\mathbf{R}(\%) \text { at } \\
55{ }^{\circ} \mathrm{C}\end{array}$ & D (\%) & $\begin{array}{l}\mathrm{R}(\%) \text { at } \\
\quad 70^{\circ} \mathrm{C}\end{array}$ & $\begin{array}{l}\text { R (\%) at } \\
55^{\circ} \mathrm{C}\end{array}$ & D (\%) & $\begin{array}{l}\text { R (\%) at } \\
70^{\circ} \mathrm{C}\end{array}$ & $\begin{array}{l}\text { R (\%) at } \\
55^{\circ} \mathrm{C}\end{array}$ & D (\%) & $\begin{array}{l}\mathrm{R}(\%) \text { at } \\
70^{\circ} \mathrm{C}\end{array}$ \\
\hline SBF 2 & 96 & 0.5 & 98 & & & & & & & & & \\
\hline SBF 20 & 95 & 0.5 & 97 & & & & & & & & & \\
\hline SBF 43 & 93 & 1.0 & 94 & & & & & & & & & \\
\hline SBF 49 & 95 & $2 \cdot 0$ & 97 & & & & & & & & & \\
\hline SBF 5 & 86 & $1 \cdot 0$ & 92 & & & & & & & & & \\
\hline SBF 21 & 92 & 1.5 & 96 & & & & & & & & & \\
\hline SBF 50 & 95 & $2 \cdot 0$ & 100 & & & & & & & & & \\
\hline SBF 40 & 97 & 1.5 & 100 & & & & & & & & & \\
\hline SBF 27 & 93 & 0.0 & 97 & & & & & & & & & \\
\hline SBF 41 & 100 & 0.0 & 100 & & & & & & & & & \\
\hline SBF 47 & 96 & $1 \cdot 0$ & 98 & & & & & & & & & \\
\hline SBF 19 & 93 & $2 \cdot 0$ & 97 & & & & & & & & & \\
\hline SBF 28 & & & & & & & 100 & 0.0 & 100 & & & \\
\hline SBF 23 & & & & 100 & 0.0 & 100 & & & & & & \\
\hline SBF 3 & & & & 96 & 2.0 & 90 & & & & & & \\
\hline SBF 8 & 45 & & & 88 & 0.0 & 90 & & & & & & \\
\hline SBF 37 & 49 & & & & & & & & & 100 & 0.0 & 100 \\
\hline icterohaemorrhagiae & 52 & & & & & & & & & 78 & 7.0 & 50 \\
\hline cynopteri & 45 & & & 88 & $1 \cdot 0$ & 90 & & & & 86 & 1.5 & 85 \\
\hline panama & 32 & & & & & & & & & 60 & & \\
\hline shermani & 53 & & & & & & & & & 36 & & \\
\hline javanica & 90 & 2.5 & 89 & & & & 82 & $2 \cdot 0$ & 90 & ND & & \\
\hline manhao 3 & 74 & $7 \cdot 0$ & 60 & & & & 70 & 7.0 & ND & 60 & & \\
\hline celledoni & 73 & 8.5 & 56 & & & & 66 & 8.0 & 51 & 46 & & \\
\hline codice & 4 & & & & & & & & & 5 & & \\
\hline lyme & 13 & & & & & & & & & 10 & & \\
\hline ranarum & 7 & & & & & & & & & 6 & & \\
\hline andamana & 3 & & & & & & & & & 5 & & \\
\hline holland & 6 & & & & & & & & & 4 & & \\
\hline illini & 6 & & & & & & & & & 6 & & \\
\hline parva & 6 & & & & & & & & & 5 & & \\
\hline
\end{tabular}

liquid nitrogen as part of the reference collection of the National Reference Laboratory at the National Animal Disease Center (Ames, IA, USA). The serovar identity of these strains had been previously verified by the National Reference Laboratory at Ames and confirmed by the WHO/FAO Collaborating Centre for Reference and Research on Leptospirosis (Amsterdam, The Netherlands) (Feresu et al., 1993, 1994, 1995, 1996, 1998, 1999).

Reference strains for the family Leptospiraceae (Table 1) were obtained from the stock culture collection of the Special Bacteriology Reference Laboratory in the Meningitis and Special Pathogens Branch at the Centers for Disease Control and Prevention (Atlanta, GA, USA). These strains were maintained in polysorbate albumin medium (PLM-5; Armour Pharmaceutical).

DNA relatedness studies. All strains were grown in polysorbate albumin medium at $30^{\circ} \mathrm{C}$ and harvested by centrifugation during their stationary phase of growth. The methods used to extract and purify DNA and the hydroxyapatite method for determining levels of DNA relatedness have been described previously (Brenner et al., 1982). Labelled DNAs from strains SBF 41, SBF 23, SBF 28 and SBF 37 were prepared enzymically in vitro with $\left[{ }^{32} \mathrm{P}\right] \mathrm{dCTP}$ by using a nick reagent kit (Bethesda Research Laboratories) as instructed by the manufacturer. Hybridization reactions were carried out at an optimal reassociation temperature of $55^{\circ} \mathrm{C}$ and at a stringent incubation temperature of $70^{\circ} \mathrm{C}$ (Yasuda et al., 1987).
Levels of relatedness were expressed as percentage values, and levels of divergence of related sequences were determined by calculating the decreases in thermal stability in heteroduplexes (reassociated labelled DNAs from two different strains) compared with the thermal stability in homoduplexes (reassociated labelled and unlabelled DNAs from the same strains). The assumption was that each $1{ }^{\circ} \mathrm{C}$ decrease in heteroduplex DNA stability was due to approximately $1 \%$ unpaired bases within the related DNA (Brenner et al., 1982), and therefore represents $1 \%$ divergence. Divergence was calculated to the nearest $0.5 \%$.

\section{RESULTS}

A species is defined as a group of strains that exhibits levels of DNA relatedness at the optimal reassociation temperature of $70 \%$ or more and whose related sequences exhibit $5 \%$ or less divergence (Wayne et al., 1987). The DNA relatedness results for the Zimbabwe strains are given in Table 2 and the species designations are in Table 1 . The 17 strains belonged to two species, Leptospira borgpetersenii and Leptospira kirschneri.

All the serogroup Pyrogenes, Hebdomadis, Sejroe and Tarassovi strains were $86 \%$ or more related at both the optimal and stringent incubation temperatures with $2 \%$ or less divergence within related sequences. These 13 strains were L. borgpetersenii, since the two of 
them that were tested (hardjo SBF 41 and mombe SBF 28) were in the same relatedness group as serovar javanica strain Veldrat Batavia $46^{\mathrm{T}}$, the type strain for L. borgpetersenii (Yasuda et al., 1987), displaying $82 \%$ or more relatedness with this strain at both temperatures with $2.5 \%$ or less divergence. At $55{ }^{\circ} \mathrm{C}$, strains SBF 41 and SBF 28 were $66-74 \%$ related to reference strains of serovars manhao 3 and celledoni but showed less relatedness, $51-60 \%$, at the more stringent $\left(70^{\circ} \mathrm{C}\right)$ temperature, and exhibited $7-8 \cdot 5 \%$ divergence. Thus the 13 strains, including those belonging to four of the new serovars, mombe (Pyrogenes), marondera and mhou (Hebdomadis) and ngavi (Tarassovi), all belonged to L. borgpetersenii.

The remaining four strains from serogroups Icterohaemorrhagiae, Australis, Pomona and Bataviae were all $88 \%$ or more interrelated, and strains SBF 23 and SBF 37 from this group were $86 \%$ or more related to serovar cynopteri strain $3522 \mathrm{C}^{\mathrm{T}}$, the type strain for $L$. kirschneri (Ramadass et al., 1992), at both temperatures with less than $2.0 \%$ divergence within related sequences. Although strain SBF 37 from this group was $78 \%$ related to $L$. interrogans at $55^{\circ} \mathrm{C}$, divergence was $7 \%$ and relatedness fell to $50 \%$ in $70^{\circ} \mathrm{C}$ reactions. Therefore this group, composed of the reference strain for the new Icterohaemorrhagiae serovar, zimbabwe, strains belonging to serovars fugis and paidjan, and a strain closely related to serovar mozdok, belonged to L. kirschneri.

\section{DISCUSSION}

Relatedness values obtained using the hydroxyapatite method reflect degrees of overall similarity between genomic DNAs of strains and hence define bacterial species in phylogenetic terms (Wayne et al., 1987). It was possible to assign all the Zimbabwe cattle isolates belonging to serogroups Icterohaemorrhagiae, Pyrogenes, Hebdomadis, Tarassovi, Sejroe, Pomona, Bataviae and Australis to already existing species of Leptospira. The isolates all belonged to either $L$. borgpetersenii or L. kirschneri.

Members of serogroup Icterohaemorrhagiae are found in five species: L. interrogans, L. borgpetersenii, Leptospira inadai, L. kirschneri and the unnamed Leptospira genomospecies 5 (Yasuda et al., 1987; Gravekamp et al., 1993; Brenner et al., 1999). Similar to the other three Icterohaemorrhagiae reference strains of serovars of African origin (mwogolo, ndambari and ndahambukuje), the reference strain of our new serovar, zimbabwe, belongs to L. kirschneri (Feresu et al., 1993; Gravekamp et al., 1993). Although strain SBF 23 was antigenically very similar to reference strains of serovars birkini, gem, lai and mwogolo (Feresu et al., 1993), all these other reference strains, except that of mwogolo, belong to $L$. interrogans (Gravekamp et al., 1993; Brenner et al., 1999).

Five of the isolates studied were members of the Pyrogenes serogroup. Three of the strains belong to our new serovar mombe, one strain belongs to serovar kwale and another strain is very closely related to serovar nigeria (Feresu et al., 1994). Pyrogenes serovars generally are found in $L$. interrogans, $L$. borgpetersenii, Leptospira noguchii, Leptospira santarosai and Leptospira weilii (Yasuda et al., 1987; Gravekamp et al., 1993; Brenner et al., 1999). All the Zimbabwe isolates together with the reference strain for serovar kwale, which is of Kenyan origin, belong to $L$. borgpetersenii. The reference strain of the only other recognized Pyrogenes serovar of African origin, nigeria, has not yet been assigned to a species.

The serogroup Hebdomadis strains included in this study belonged to two new serovars, marondera and mhou (Feresu et al., 1996). Members of serogroup Hebdomadis are found in six species, $L$. interrogans, $L$. borgpetersenii, L. santarosai, L. weilii, L. kirschneri and in Leptospira genomospecies 2 (Yasuda et al., 1987; Ramadass et al., 1992; Gravekamp et al., 1993; Brenner et al., 1999). Reference strains of four of the serogroup Hebdomadis serovars, kabura, kambale, jules and nona, are of Zairian origin (Kmety \& Dikken, 1993). Those of serovars jules and nona belong to $L$. borgpetersenii while those of serovars kabura and kambale belong to L. kirschneri (Ramadass et al., 1992; Brenner et al., 1999). The reference strains for the new serovars marondera and mhou belong to $L$. borgpetersenii similar to serovars jules and nona. A close relationship based on their PFGE restriction patterns had been previously observed among these four serovars (Feresu et al., 1996).

One of the strains, SBF 19, included in the study belongs to the new serovar ngavi, in serogroup Tarassovi (Feresu et al., 1998). Serovars of serogroup Tarassovi are found in five species, $L$. borgpetersenii, $L$. inadai, L. noguchii, L. santarosai and $L$. weilii (Yasuda et al., 1987; Ramadass et al., 1992; Gravekamp et al., 1993; Brenner et al., 1999). Like the other serogroup Tarassovi strains of African origin (the reference strains for serovars kisuba, kanana and tunis), strain SBF 19 belongs to $L$. borgpetersenii (Gravekamp et al., 1993; Brenner et al., 1999). In earlier studies, strain SBF 19 had RFLP patterns which were very similar to those of reference strains of serovars tarassovi, guidae, tunis and mouldaviae which could not be distinguished by restriction analysis alone (Feresu et al., 1998). The restriction patterns could only be distinguished after their Southern blots had been hybridized with a probe synthesized from a repetitive sequence element cloned from serovar hardjo strain Hardjo-bovis (Zuerner et al., 1993; Feresu et al., 1998). Reference strains for these four closely related serovars also belong to $L$. borgpetersenii (Ramadass et al., 1992; Gravekamp et al., 1993; Brenner et al., 1999).

Most strains (31) isolated from the cattle belonged to serogroup Sejroe serovar hardjo (Feresu, 1992). They were identified as being similar to strain Hardjo-bovis (Feresu \& Bolin, 1991). Two representatives of these strains were included in this study. Serogroup Sejroe strains are found in L. interrogans, L. borgpetersenii, $L$. 
santarosai, L. weilii and Leptospira meyeri (Van Eys et al., 1991; Gravekamp et al., 1993; Brenner et al., 1999). Like all the other Hardjo-bovis strains characterized to date, our two isolates belonged to $L$. borgpetersenii.

One of the Sejroe strains, SBF 47, belongs to serovar balcanica (Feresu \& Bolin, 1991). Although the chromosomal DNA of the isolate had a distinct RFLP pattern from that of the balcanica reference strain (Feresu \& Bolin, 1991), both strains belong to $L$. borgpetersenii.

Identification of the Zimbabwe serogroup Pomona strain SBF 8 was equivocal (Feresu et al., 1995) as the isolate showed a close similarity to serovars mozdok and proechimys by cross-agglutinin absorption test and to serovar pomona by mAbs but had a unique chromosomal DNA RFLP pattern. Serogroup Pomona strains are found in $L$. interrogans, $L$. noguchii, L. santarosai and L. kirschneri (Van Eys et al., 1991; Ramadass et al., 1992; Gravekamp et al., 1993; Brenner et al., 1999). Strain SBF 8 was identified as belonging to L. kirschneri in agreement with the results obtained using PCR with primer sets $\mathrm{G} 1 / \mathrm{G} 2$ and B64-I/B64-II (Gravekamp et al., 1993; Feresu et al., 1995). The reference strains of serovars mozdok, proechimys and pomona, respectively, belong to $L$. kirschneri, L. noguchii and L. interrogans (Van Eys et al., 1991; Gravekamp et al., 1993; Brenner et al., 1999). Our results confirm strain SBF 8 as a variant within serovar mozdok.

A single strain, SBF 3, belonging to serovar fugis of serogroup Australis was included in the study (S. B. Feresu, unpublished results). Australis strains are found in L. interrogans, L. kirschneri, L. borgpetersenii and L. noguchii (Ramadass et al., 1992; Gravekamp et al., 1993; Brenner et al., 1999). The fugis isolate (SBF 3 ) belongs to L. kirschneri, unlike the reference strain of serovar fugis (Fudge), a Malaysian patient isolate, which belongs to L. interrogans (Ramadass et al., 1992; Gravekamp et al., 1993). Similar species assignments were obtained for SBF 3 and the Fudge reference strains from both the Atlanta and Amsterdam culture collections using PCR reactions with primer sets G1/G2 and B64-I/B64-II (Gravekamp et al., 1993; S. B. Feresu \& A. Whitney, unpublished results). The only other African Australis strain whose species has been determined is the reference strain for serovar ramisi, which also belongs to L. kirschneri.

Bataviae serovars are found in five species, $L$. interrogans, $L$. noguchii, $L$. santarosai, L. kirschneri and Leptonema illini (Gravekamp et al., 1993; Brenner et al., 1999). One of the Zimbabwe cattle strains, SBF 37, belonged to serogroup Bataviae, serovar paidjan (Feresu et al., 1999), species L. kirschneri. This was unlike the reference strain for serovar paidjan, a patient isolate from Indonesia, which belongs to $L$. interrogans. Similar species identities were obtained for SBF 37 and the Paidjan reference strains from both the Amsterdam and Atlanta culture collections in PCR reactions using primer sets G1/G2 and B64-I/B64-II (Feresu et al., 1999; S. B. Feresu \& A. Whitney, unpublished results). The only other known serogroup Bataviae leptospire which belongs to L. kirschneri is the reference strain for serovar djatzi, a human isolate from Puerto Rico (Gravekamp et al., 1993; Brenner et al., 1999). There are no Bataviae reference strains isolated from Africa which could be used for comparison.

Similar to previous observations (Van Eys et al., 1991; Zuerner et al., 1993; Perolat et al., 1994; Brenner et al., 1999), our study has demonstrated a possible correlation between the genotype and geographical origin of a strain. So far all of the 37 African Leptospira strains whose DNA relatedness has been determined belong to either L. kirschneri (16) or L. borgpetersenii (21) (Feresu et al., 1995; Brenner et al., 1999; this study). Ramadass et al. (1992) derived a phylogenetic tree in which six of the pathogenic Leptospira species were shown to have originated from two ancestors, resulting in two groups: the L. kirschneri, L. interrogans and $L$. noguchii group and the $L$. borgpetersenii, $L$. santarosai and $L$. weilii group. Thus there appears to be limited species diversity on the African continent as only a single species from each group has been isolated so far.

All the L. kirschneri strains identified in this study are either members of a serovar in which the reference strain belongs to $L$. interrogans or are antigenically closely related to serovars which belong to $L$. interrogans. This is interesting as $L$. interrogans is the closest relative of $L$. kirschneri on the phylogenetic tree (Ramadass et al., 1992).

Generally, the African strains within a serogroup belong to the same species; thus, the Hebdomadis serogroup in which the four African serovars belong to either L. interrogans or L. kirschneri is worth noting.

\section{ACKNOWLEDGEMENTS}

Isolation work was financed by grants from the University of Zimbabwe Research Board and the International Foundation for Science. S.B.F. was sponsored by the Fulbright Fellowship for a 12 month sabbatical at the Centers for Disease Control. The manuscript was written at the Rockefeller Foundation Bellagio Study and Conference Center. S.B.F. was sponsored by the Rockefeller Foundation for a month's residency.

\section{REFERENCES}

Brenner, D. J., McWhorter, A. C., Leete Knutson, J. K. \& Steigerwalt, A. G. (1982). Escherichia vulneris: a new species of Enterobacteriaceae associated with human wounds. $J$ Clin Microbiol 15, 1133-1140.

Brenner, D. J., Kaufmann, A. F., Sulzer, K. R., Steigerwalt, A. G., Rogers, F. C. \& Weyant, R. S. (1999). Further determination of DNA relatedness between serogroups and serovars in the family Leptospiraceae with a proposal for Leptospira alexanderi $\mathrm{sp}$. nov. and four new Leptospira genomospecies. Int $J$ Syst Bacteriol 49, 839-858. 
de Caballero, O. L. S. D., Neto, E. D., Koury, M. C., Romanha, A. J. \& Simpson, A. J. G. (1994). Low-stringency PCR with diagnostically useful primers for identification of Leptospira serovars. J Clin Microbiol 32, 1369-1372.

Corney, B. G., Colley, J., Djordjevic, S.P., Whittington, R. \& Graham, G. C. (1993). Rapid identification of some Leptospira isolates from cattle by random amplified polymorphic DNA fingerprinting. J Clin Microbiol 31, 2927-2932.

Ellis, W. A., Montgomery, J. M. \& Thiermann, A. B. (1991). Restriction endonuclease analysis as a taxonomic tool in the study of pig isolates belonging to the Australis serogroup of Leptospira interrogans. J Clin Microbiol 29, 957-961.

Feresu, S. B. (1992). Isolation of Leptospira interrogans from kidneys of Zimbabwe beef cattle. Vet Rec 130, 446-448.

Feresu, S. B. \& Bolin, C. A. (1991). Characterization of Leptospira interrogans isolated from cattle in Zimbabwe. In Leptospirosis. Proceedings of the Leptospirosis Research Conference 1990, pp. 215-224. Edited by Y. Kobayashi. Tokyo: University of Tokyo.

Feresu, S. B., Bolin, C. A. \& Korver, H. (1993). A new leptospiral serovar in the Icterohaemorrhagiae serogroup isolated from an ox in Zimbabwe. Int $J$ Syst Bacteriol 43, 179-182.

Feresu, S. B., Bolin, C. A., Korver, H. \& Terpstra, W. J. (1994). Classification of leptospires of the Pyrogenes serogroup isolated from cattle in Zimbabwe by cross-agglutinin absorption and restriction fragment length polymorphism analysis. Int $J$ Syst Bacteriol 44, 541-546.

Feresu, S. B., Bolin, C. A., Korver, H. \& Van De Kemp، H. (1995). Identification of leptospires of the Pomona and Grippotyphosa serogroups isolated from cattle in Zimbabwe. Res Vet Sci 59, 92-94.

Feresu, S. B., Korver, H., Riquelme, N., Baranton, G. \& Bolin, C. A. (1996). Two new leptospiral serovars in the Hebdomadis serogroup isolated from Zimbabwe cattle. Int J Syst Bacteriol 46, 694-698.

Feresu, S. B., Bolin, C. A. \& Korver, H. (1998). A new leptospiral serovar ngavi in the Tarassovi serogroup isolated from Zimbabwe oxen. Int $J$ Syst Bacteriol 48, 207-213.

Feresu, S. B., Bolin, C. A., Van De Kemp, H. \& Korver, H. (1999). Identification of a serogroup Bataviae Leptospira strain isolated from an ox in Zimbabwe. Zentbl Bakteriol 289, 19-29.

Gravekamp, C., Van de Kemp, H., Franzen, M., Carrington, D., Schoone, G. J., Van Eys, G. J. J. M., Everard, C. O. R., Hartskeerl, R. A. \& Terpstra, W. J. (1993). Detection of seven species of pathogenic leptospires by PCR using two sets of primers. J Gen Microbiol 139, 1691-1700.

Herrmann, J. L., Baril, C., Bellenger, E., Perolat, P., Baranton, G. \& Saint Girons, I. (1991). Genome conservation in isolates of Leptospira interrogans. J Bacteriol 173, 7582-7588.

Herrmann, J. L., Bellenger, E., Perolat, P., Baranton, G. \& Saint Girons, I. (1992). Pulsed-field gel electrophoresis of NotI digests of leptospiral DNA: a new rapid method of serovar identification. J Clin Microbiol 30, 1696-1702.

Hookey, J. V. (1990). The detection of genetic variation in Leptospira interrogans serogroup Icterohaemorrhagiae by ribosomal RNA gene restriction fragment patterns. FEMS Microbiol Lett 72, 329-336.

Hookey, J. v. (1992). Detection of Leptospiraceae by amplification of $16 \mathrm{~S}$ ribosomal DNA. FEMS Microbiol Lett 90 , 267-274.

Hookey, J. V. (1993). Characterization of Leptospiraceae by $16 \mathrm{~S}$ DNA restriction fragment length polymorphisms. J Gen Microbiol 139, 1681-1689.
Johnson, R. C. \& Faine, S. (1984). Family II. Leptospiraceae Hovind-Hougen 1979, 245 ${ }^{\mathrm{AL}}$. In Bergey's Manual of Systematic Bacteriology, vol. 1, pp. 62-67. Edited by N. R. Krieg \& J. G. Holt. Baltimore: Williams \& Wilkins.

Kmety, E. \& Dikken, H. (1993). Classification of the Species Leptospira interrogans and History of its Serovars. Groningen: University Press Groningen.

Le Febvre, R. B. (1987). DNA probe for detection of the Leptospira interrogans serovar hardjo genotype Hardjo-bovis. $J$ Clin Microbiol 25, 2236-2238.

Letocart, M., Baranton, G. \& Perolat, P. (1997). Rapid identification of pathogenic Leptospira species (L. interrogans, $L$. borgpetersenii and $L$. kirschneri) with species-specific DNA probes produced by arbitrarily primed PCR. J Clin Microbiol 35, 248-253.

Marshall, R. B., Wilton, B. E. \& Robinson, A. J. (1981). Identification of Leptospira serovars by restriction-endonuclease analysis. J Med Microbiol 14, 163-166.

Mérien, F., Amouriaux, P., Perolat, P., Baranton, G. \& Saint Girons, I. (1992). Polymerase chain reaction for detection of Leptospira spp. in clinical samples. J Clin Microbiol $\mathbf{3 0}$, 2219-2224.

Millar, B. D., Chappel, R. J. \& Adler, B. (1987). Detection of leptospires in biological fluids using DNA hybridisation. Vet Microbiol 15, 71-78.

Murgia, R., Riquelme, N., Baranton, G. \& Cinco, M. (1997). Oligonucleotides specific for pathogenic and saprophytic Leptospira occurring in water. FEMS Microbiol Lett 148, 27-34.

Nielsen, J. N., Armstrong, C. H. \& Nielsen, N. C. (1989). Relationship among selected Leptospira interrogans serogroups as determined by nucleic acid hybridization. J Clin Microbiol 27, 2724-2729.

Pacciarini, M. L., Savio, M. L., Tagliabue, S. \& Rossi, C. (1992). Repetitive sequences cloned from Leptospira interrogans serovar hardjo genotype Hardjoprajitno and their application to serovar identification. J Clin Microbiol 30, 1243-1249.

Pérolat, P., Grimont, F., Regnault, B., Grimont, P. A. D., Fournié, E., Thevenet, H. \& Baranton, G. (1990). rRNA gene restriction patterns of Leptospira: a molecular typing system. Res Microbiol 141, 159-171.

Perolat, P., Lecuyer, I., Postic, D. \& Baranton, G. (1993). Diversity of ribosomal DNA fingerprints of Leptospira serovars provides a database for subtyping and species assignation. Res Microbiol 144, 5-15.

Perolat, P., Merien, F., Ellis, W. A. \& Baranton, G. (1994). Characterization of Leptospira isolates from serovar hardjo by ribotyping, arbitrarily primed PCR, and mapped restriction site polymorphisms. J Clin Microbiol 32, 1949-1957.

Perolat, P., Chappel, R. J., Adler, B., Baranton, G., Bulach, D. M., Billinghurst, M. L., Letocart, M., Merien, F. \& Serrano, M. S. (1998). Leptospira fainei sp. nov., isolated from pigs in Australia. Int $J$ Syst Bacteriol 48, 851-858.

Ralph, D., McClelland, M., Welsh, J., Baranton, G. \& Perolat, P. (1993). Leptospira species categorized by arbitrarily primed polymerase chain reaction (PCR) and by mapped restriction polymorphisms in PCR-amplified rRNA genes. $J$ Bacteriol 175, 973-981.

Ramadass, P., Jarvis, B. D. W., Corner, R. J., Penny, D. \& Marshall, R. B. (1992). Genetic characterization of pathogenic Leptospira species by DNA hybridization. Int J Syst Bacteriol 42, 215-219. Terpstra, W. J., Schoone, G. J., Ligthart, G. S. \& Ter Schegget, J. (1987). Detection of Leptospira interrogans in clinical specimens 
by in situ hybridization using biotin-labelled DNA probes. J Gen Microbiol 133, 911-914.

Thiermann, A. B., Handsaker, A. L., Foley, J. W., White, F. H. \& Kingscote, B. F. (1986). Reclassification of North American leptospiral isolates belonging to serogroups Mini and Sejroe by restriction endonuclease analysis. Am $J$ Vet Res 47, 61-66.

Van Eys, G. J. J. M., Gravekamp, C., Gerritsen, M. J., Quint, W., Cornelissen, M. T. E., Ter Schegget, J. \& Terpstra, W. J. (1989). Detection of leptospires in urine by polymerase chain reaction. $J$ Clin Microbiol 27, 2258-2262.

Van Eys, G. J. J. M., Gerritsen, M. J., Korver, H., Schoone, G. J., Kroon, C. C. M. \& Terpstra, W. J. (1991). Characterization of serovars of the genus Leptospira by DNA hybridization with Hardjo-bovis and Icterohaemorrhagiae recombinant probes with special attention to serogroup Sejroe. J Clin Microbiol 29, 1042-1048.

Wayne, L. G., Brenner, D. J., Colwell, R. R. \& 9 other authors (1987). International Committee on Systematic Bacteriology. Report of the ad hoc committee on reconciliation of approaches to bacterial systematics. Int J Syst Bacteriol 37, 463-464.

Woodward, M. J. \& Sullivan, G. J. (1991). Nucleotide sequence of a repetitive element isolated from Leptospira interrogans serovar hardjo type Hardjo-bovis. J Gen Microbiol 137, 1101-1109.

Yasuda, P. H., Steigerwalt, A. G., Sulzer, K. R., Kaufmann, A. F., Rogers, F. \& Brenner, D. J. (1987). Deoxyribonucleic acid relatedness between serogroups and serovars in the family Leptospiraceae with proposals for seven new Leptospira species. Int J Syst Bacteriol 37, 407-415.

Zuerner, R. L. \& Bolin, C. A. (1988). Repetitive sequence element cloned from Leptospira interrogans serovar hardjo type Hardjobovis provides a sensitive diagnostic probe for bovine leptospirosis. J Clin Microbiol 26, 2495-2500.

Zuerner, R. L. \& Bolin, C. A. (1990). Nucleic acid probe characterizes Leptospira interrogans serovars by restriction fragment length polymorphisms. Vet Microbiol 24, 355-366.

Zuerner, R. L., Ellis, W. A., Bolin, C. A. \& Montgomery, J. M. (1993). Restriction fragment length polymorphisms distinguish Leptospira borgpetersenii serovar hardjo type Hardjo-bovis isolates from different geographical locations. J Clin Microbiol 31, 578-583.

Zuerner, R. L., Alt, D. \& Bolin, C. A. (1995). IS1533-based PCR assay for identification of Leptospira interrogans sensu lato serovars. J Clin Microbiol 33, 3284-3289. 